\title{
Conservation planning following reclamation of intertidal areas throughout the Yellow and Bohai Seas, China
}

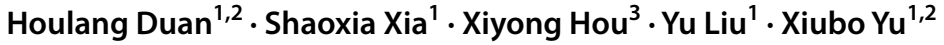

Received: 8 January 2019 / Revised: 22 August 2019 / Accepted: 27 August 2019 /

Published online: 31 August 2019

(c) Springer Nature B.V. 2019

\begin{abstract}
Tidal flats throughout the Yellow and Bohai Seas provide essential habitat for migrating shorebirds along the East Asian-Australasian Flyway. Land reclamation threatens this habitat. Using bird-sighting data and environmental variables, we identify areas appropriate for prioritized protection for 46 shorebird species, using a MaxEnt species distribution model and Zonation protection planning software. We also assess changes in habitat status and conservation importance of tidal flats along the Rudong and Dongtai coasts, Jiangsu Province, a significant shorebird biodiversity area recently inscribed as a World Heritage site. A priority area of $4523 \mathrm{~km}^{2}$, containing more saltpan and aquaculture areas than tidal flats, and more than $90 \%$ of all tidal flat areas in the priority area, is identified, of which only $12.05 \%$ is currently protected within existing National Nature Reserves. Tidal flats along the Rudong and Dongtai coasts have decreased in area from 2000 to 2015, and particularly from 2010 to 2015 at a rate nine times that for 2000-2010. An irreplaceability index for coastal habitat for Xiaoyangkou, Rudong county, increased from 2012 to 2015, signaling a need for urgent habitat management and protection, such as afforded by establishing new nature reserves. Effective management and restoration of saltpan and aquaculture habitat in Bohai and Laizhou bays is also necessary.
\end{abstract}

Keywords Shorebirds $\cdot$ Migration $\cdot$ Conservation $\cdot$ China $\cdot$ MaxEnt $\cdot$ Zonation

Communicated by Anurag chaurasia.

Houlang Duan and Shaoxia Xia have contributed equally to this work.

Electronic supplementary material The online version of this article (https://doi.org/10.1007/s1053 1-019-01851-3) contains supplementary material, which is available to authorized users.

Xiubo Yu

yuxb@igsnrr.ac.cn

1 Key Laboratory of Ecosystem Network Observation and Modeling, Institute of Geographic Sciences and Natural Resources Research, Chinese Academy of Sciences, Beijing 100101, China

2 College of Resources and Environment, University of Chinese Academy of Sciences, Beijing 100190, China

3 Yantai Institute of Coastal Zone Research, Chinese Academy of Sciences, Yantai 264003, China 


\section{Introduction}

Most shorebirds are long-distance migrants, of which millions undertake a return migration from North East Asia to coastal non-breeding areas each year, for wintering and breeding (Melville et al. 2016). For these migrants, the intertidal areas of the Yellow and Bohai Seas in China represent important staging and non-breeding areas along the East Asian-Australasian Flyway (EAAF) (Battley 2004; Hua et al. 2015; Chen et al. 2015). These intertidal areas support large numbers of shorebird species (Studds et al. 2017), with more than 1\% of the populations of more than 20 species or subspecies of shorebirds occurring here (Bai et al. 2015; Xia et al. 2016). The coasts of Rudong and Dongtai counties in Jiangsu province also provide habitat for four species of shorebird classified as threatened by the IUCN: the spoon-billed sandpiper Calidris pygmaea, great knot $C$. tenuirostris, spotted greenshank Tringa guttifer, and eastern curlew Numenius madagascariensis (Tong et al. 2014; Peng et al. 2017a, b).

The impact of coastal wetland reclamation in the Yellow and Bohai Seas on long-distance migrating shorebirds is of concern (Ma et al. 2010; Melville et al. 2016; Studds et al. 2017). From 2000 to 2014, populations of some shorebird species dependent on tidal mudflats as stopover sites declined rapidly because of habitat loss and degradation (Murray et al. 2014, 2015; Murray and Fuller 2015; Studds et al. 2017). In particular, significant habitat for migratory shorebirds along the coasts of Rudong and Dongtai has been lost (Peng et al. 2017a; Piersma et al. 2017), with tidal flats converted to construction land unsuitable for shorebirds (Murray et al. 2015; Murray and Fuller 2015), or for aquaculture or saltpan use, suitable for shorebirds only during specific periods (Sánchez et al. 2006; Yasué and Dearden 1992, 2009). Recently (25 March 2018) an area along the Rudong and Dongtai coastline was nominated as a World Heritage site (IUCN World Heritage Evaluations 2019), and on July 5, 2019, an area in Tiaozini, Dongtai county, was inscribed in the World Heritage list.

Although many natural reserves (NRs) have been established within the Yellow and Bohai Seas to protect waterbird habitat, the protection these reserves afford is not always effective (Watson et al. 2014). Boundary adjustments to national NRs, land exploitation within NRs, and environmental changes have decreased available tidal flat area, possibly influencing the distributions of bird species (Ma et al. 2019; Yang et al. 2011). Intense conflict also exists between the competing needs of economic development and biodiversity conservation (Ma et al. 2019).

Enlarging NRs to improve shorebird protection may mitigate against some adverse environmental impacts (Ma et al. 2019). To do so, identifying priority areas and implementing conservation planning are necessary (Zwiener et al. 2017; Triviño et al. 2018). Here we use a SDM and protection planning software to identify remaining tidal flat areas in the Yellow and Bohai Seas appropriate for prioritized conservation for the protection of 46 important shorebird species. Areas where appropriate conservation is lacking (gaps) are also identified. We ascertain: (1) where conservation priority areas for migratory shorebird species occur; (2) whether current protection networks adequately protect migratory shorebirds; and (3), how the habitat status and conservation importance of the coast in Rudong and Dongtai counties, Jiangsu province (in a inscribed World Heritage site), has changed due to land reclamation. 


\section{Data and methodology}

\section{Study area}

The coasts of the Yellow and Bohai Seas in China include the six provinces or municipalities of Liaoning; Hebei; Tianjin; Shandong; Jiangsu, and Shanghai (Fig. 1), wherein the total wetland area, primarily permanently shallow marine habitat (of water depth less than $6 \mathrm{~m}$ at low tide, according to Ramsar Convention), is $10.6 \times 10^{3} \mathrm{~km}^{2}$. Between 2000 and 2014 , tidal flats throughout this region have been subjected to large-scale reclamation. Considerable habitat has been lost, and declines in populations of some shorebirds have

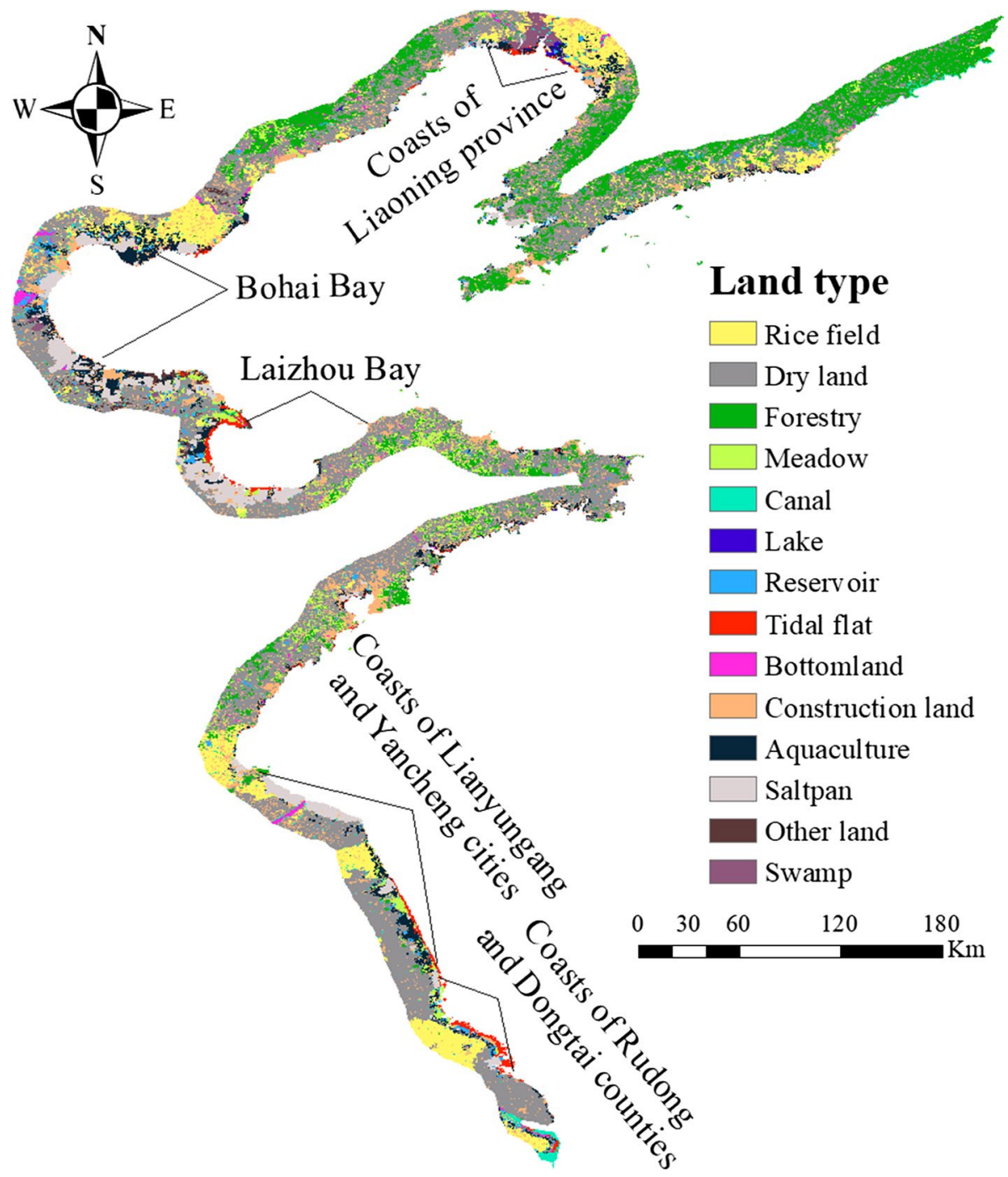

Fig. 1 The location of the Study area 
been reported (Ma et al. 2015). Until 2014, this area included 15 national nature reserves, 19 important bird areas, and six Ramsar sites.

\section{Shorebird occurrence data}

Waterbird occurrence data were sourced from Bird Report (http://www.birdreport.cn/, 2015) for typical shorebird species in the Yellow and Bohai Seas in China. Data were filtered according to: (1) species highly dependent on coasts in Yellow and Bohai Seas (BirdLife International 2019; Bai et al. 2015); and (2) examples where bird-occurrence records exceeded five within an area (the requirement of the species distribution model). Resulting data for 46 shorebirds from 1634 independent coordinate survey sites were sourced for this study (Table 1). These shorebirds include one Critically Endangered species (CR), three Endangered species (EN), 10 Near Threatened species (NT), and 32 Least Concern species (LC) (IUCN 2019). Data for these 46 shorebird species were entered into MaxEnt model.

\section{Environmental variables}

Our environmental variables included land use, bioclimate (including annual precipitation and temperature), topography (including elevation, slope and aspect), distance to water, human disturbance (including distance to road, settlement, population density), and a Normalized Difference Vegetation Index (NDVI). Most data were downloaded from the Data Center for Resources and Environmental Sciences at the Chinese Academy of Sciences (RESDC) (http://www.resdc.cn). Most environmental data were collected in 2015-a turning point for tidal flat reclamation in China, with nearly all reclamation activities halted by central government (Paulson Institute 2016) —although some from 2016 were used (please see Table $\mathrm{S} 1$ for a data summary).

Data with $1 \mathrm{~km}$ resolution ended up merging four land use categories (saltpans, aquaculture, oil fields and ports) into a single category labeled 'construction land.' However, birdwatching records and the literature indicated saltpan and aquaculture lands in these areas were also important for shorebirds (Melville et al. 2016; Niu 2013). Therefore, we extracted saltpan and aquaculture areas from land-use data with $30 \mathrm{~m}$ resolution (sourced from the Yantai Institute of Coastal Zone Research, Chinese Academy of Sciences), and then used these data to modify existing $1 \mathrm{~km}$ resolution land-use data. Most shorebirds were highly dependent on wetlands in the coastal region, so we restricted our analysis a priori to these habitats, retaining data for wetland types such as rice fields, canals, lakes, reservoirs, tidal flats, bottomland, aquaculture, saltpans and swamps in our analysis.

Slope and aspect data were extracted from a digital elevation model (DEM). Distance to water, distance to roads, and settlement data were calculated based on the river system from the DEM, and the distributions of roads and settlements was determined using the raster calculator tool in ArcGIS10.5. All environment variables were resampled to $1 \mathrm{~km}$ resolution and transformed to ASCII type, then masked by the study area scale.

\section{Species distribution model}

We used MaxEnt 3.1.1 (http://www.cs.princeton.edu/*schapire/maxent/) to model the potential distributions of target shorebird species. This model calculated the constraints of the target species distribution from the environmental characteristics of species occurrence sites, 
Table 1 Inventory of 46 shorebird species in the study area-IUCN status: critically endangered species (CR), endangered species (EN), near threatened species (NT), least concern species (LC)

\begin{tabular}{|c|c|c|c|c|c|}
\hline Family & Code & English name & Latin Name & $\begin{array}{l}\text { Number of } \\
\text { occur- } \\
\text { rences }\end{array}$ & IUCN Category \\
\hline Haematopodidae & 1 & Eurasian Oystercatcher & Haematopus ostralegus & 44 & NT \\
\hline \multirow[t]{2}{*}{ Recurvirostridae } & 2 & Black-winged Stilt & $\begin{array}{l}\text { Himantopus himan- } \\
\text { topus }\end{array}$ & 47 & $\mathrm{LC}$ \\
\hline & 3 & Pied Avocet & Recurvirostra avosetta & 23 & $\mathrm{LC}$ \\
\hline \multirow[t]{8}{*}{ Charadriidae } & 4 & Pacific Golden Plover & Pluvialis fulva & 59 & $\mathrm{LC}$ \\
\hline & 5 & Grey Plover & Pluvialis squatarola & 18 & $\mathrm{LC}$ \\
\hline & 6 & Common Ringed Plover & Charadrius hiaticula & 15 & $\mathrm{LC}$ \\
\hline & 7 & Long-billed Plover & Charadrius placidus & 14 & $\mathrm{LC}$ \\
\hline & 8 & Little Ringed Plover & Charadrius dubius & 44 & $\mathrm{LC}$ \\
\hline & 9 & Kentish Plover & $\begin{array}{l}\text { Charadrius alexan- } \\
\text { drinus }\end{array}$ & 31 & LC \\
\hline & 10 & Lesser Sand plover & Charadrius mongolus & 31 & $\mathrm{LC}$ \\
\hline & 11 & Greater Sand Plover & $\begin{array}{l}\text { Charadrius } \\
\text { leschenaultii }\end{array}$ & 47 & LC \\
\hline \multirow[t]{26}{*}{ Scolopacidae } & 12 & Eurasian Woodcock & Scolopax rusticola & 25 & $\mathrm{LC}$ \\
\hline & 13 & Pintail Snipe & Gallinago stenura & 17 & $\mathrm{LC}$ \\
\hline & 14 & Swinhoe's Snipe & Gallinago megala & 25 & $\mathrm{LC}$ \\
\hline & 15 & Common Snipe & Gallinago gallinago & 66 & $\mathrm{LC}$ \\
\hline & 16 & Asian Dowitcher & $\begin{array}{l}\text { Limnodromus semipa- } \\
\text { lmatus }\end{array}$ & 10 & NT \\
\hline & 17 & Black-tailed Godwit & Limosa limosa & 40 & NT \\
\hline & 18 & Bar-tailed Godwit & Limosa lapponica & 39 & NT \\
\hline & 19 & Little Curlew & Numenius minutus & 24 & $\mathrm{LC}$ \\
\hline & 20 & Whimbrel & Numenius phaeopus & 74 & $\mathrm{LC}$ \\
\hline & 21 & Eurasian Curlew & Numenius arquata & 38 & NT \\
\hline & 22 & Far Eastern Curlew & $\begin{array}{l}\text { Numenius madagas- } \\
\text { cariensis }\end{array}$ & 16 & EN \\
\hline & 23 & Spotted Redshank & Tringa erythropus & 19 & $\mathrm{LC}$ \\
\hline & 24 & Common Redshank & Tringa totanus & 35 & $\mathrm{LC}$ \\
\hline & 25 & Marsh Sandpiper & Tringa stagnatilis & 63 & $\mathrm{LC}$ \\
\hline & 26 & Common Greenshank & Tringa nebularia & 47 & $\mathrm{LC}$ \\
\hline & 27 & Spotted Greenshank & Tringa guttifer & 13 & EN \\
\hline & 28 & Green Sandpiper & Tringa ochropus & 41 & $\mathrm{LC}$ \\
\hline & 29 & Grey-tailed tattler & Heteroscelus brevipes & 39 & NT \\
\hline & 30 & Terek Sandpiper & Xenus cinereus & 69 & $\mathrm{LC}$ \\
\hline & 31 & Common Sandpiper & Actitis hypoleucos & 52 & $\mathrm{LC}$ \\
\hline & 32 & Ruddy Turnstone & Arenaria interpres & 53 & $\mathrm{LC}$ \\
\hline & 33 & Great Knot & Calidris tenuirostris & 37 & EN \\
\hline & 34 & Red Knot & Calidris canutus & 11 & NT \\
\hline & 35 & Sanderling & Calidris alba & 22 & $\mathrm{LC}$ \\
\hline & 36 & Red-necked Stint & Calidris ruficollis & 70 & NT \\
\hline & 37 & Spoon-billed sandpiper & Calidris pygmaea & 15 & $\mathrm{CR}$ \\
\hline
\end{tabular}


Table 1 (continued)

\begin{tabular}{|c|c|c|c|c|c|}
\hline Family & Code & English name & Latin Name & $\begin{array}{l}\text { Number of } \\
\text { occur- } \\
\text { rences }\end{array}$ & IUCN Category \\
\hline & 38 & Little Stint & Calidris minuta & 20 & $\mathrm{LC}$ \\
\hline & 39 & Temminck's Stint & Calidris temminckii & 25 & $\mathrm{LC}$ \\
\hline & 40 & Sharp-tailed Sandpiper & Calidris acuminata & 17 & NT \\
\hline & 41 & Broad-billed Sandpiper & Limicola falcinellus & 65 & $\mathrm{LC}$ \\
\hline & 42 & Ruff & Philomachus pugnax & 27 & $\mathrm{LC}$ \\
\hline & 43 & Curlew Sandpiper & Calidris ferruginea & 30 & NT \\
\hline & 44 & Dunlin & Calidris alpina & 51 & $\mathrm{LC}$ \\
\hline & 45 & Red-necked Phalarope & Phalaropus lobatus & 23 & $\mathrm{LC}$ \\
\hline Glareolidae & 46 & Oriental Pratincole & Glareola maldivarum & 43 & $\mathrm{LC}$ \\
\hline
\end{tabular}

and explored the possible distribution of maximum entropy under the constraints (Harte and Newman 2014). One advantage of MaxEnt is that it can model species distributions from few occurrence sites (Hu et al. 2017); our records included observations of species from 10 to 74 sites.

For each shorebird species, sites at which they occurred and environmental variables were selected automatically when running the model. We used the "Jackknife test" and "create response curves" to determine the importance of environmental variables to the distributions of each species. We set "cross-validate" in the replicated run type, and the model was set to run 10 times. Default settings were used for all other parameters (Wu et al. 2018). Average outputs of the 10 cross-validation model runs were used in analysis. The area under the curve (AUC) was used to assess the model effect, with a value above 0.7 assumed to be favorable ( $\mathrm{Li}$ et al. 2017; Nori et al. 2013).

\section{Identification of priority areas and gap analysis}

To identify priority areas within the study area, we used the Zonation model, a software package specifically designed for large-scale spatial conservation planning (http://www. syke.fi/en-US/Research__development/Ecosystem_services/Specialist_work/Zonation_ in_Finland/Zonation_software). This model can evaluate existing or proposed reserve networks, and provide advice on reserve and protection site selection (Moilane et al. 2014). Zonation facilitates planning of core protection areas based on species protection values more so than models used in previous studies (Bastos 2013; Alagador et al. 2016). The potential distributions of the 46 target shorebird species, calculated by MaxEnt, were used as inputs to Zonation.

When designing conservation priority areas, we weighted target species according to their IUCN conservation status, with species classified CR, EN, NT and LC weighted 5, 4,2 , and 1, respectively. The grid removal rule of "Core Area Zonation" was adopted to minimize biological loss when running the model (Spiers et al. 2018). In addition, we used the edge removal rule to maintain structural connectivity during the removal process. The warping factor (that determined the run time and precision) was set at 1 to ensure the optimization operation worked correctly. Other parameters were set to default values.

The Zonation output is a nested hierarchical landscape sequence. This was divided into four value categories of low, high, very high, and extremely high protection, using the 
natural break in ArcGIS 10.5 software. Excluding low protection value areas, remaining areas were selected as priority areas for shorebirds. We then overlaid these priority areas and the spatial distribution of National Nature Reserves (NNRs) (sourced from Institute of Geographic Sciences and Natural Resources Research, CAS, http://www.igsnrr.ac.cn/) to assess conservation status and conservation gaps. Data processing and spatial analysis used ArcGIS10.5 software.

\section{Changes in habitat status and conservation importance along the coasts of Rudong and Dongtai counties}

We focus on the Rudong and Dongtai counties (Jiangsu province) given this area was recently inscribed as a World Heritage site. We use land use and land cover data from 2000 to 2015 to detect changes in habitat status. As bird count data (China Coastal Waterbird Census data) were not available for the coasts of Dongtai county, we used bird count data from Xiaoyangkou (Rudong county) only - a site recognized as internationally important for shorebirds (Bai et al. 2015). To evaluate changes in the importance to conservation of habitat throughout Xiaoyangkou we calculated an irreplaceability index [I, Eq. (1) below (Xia et al. 2016)] for the period between 2008 and 2015. Areas in which a significant proportion of the population of specific species, or in which high abundances occur, are considered to have high conservation importance (Ramsar Convention Secretariat 2010). The greater the $I$ value the greater the importance of a site for conservation.

$$
I=\sum_{i=1}^{s} n_{i} /{ }_{N} \times w_{i} \times 100
$$

In this equation $s$ denotes the number of species (46); $n_{i}$ is the count number of the $i$ th species at a survey site each year (we selected the maximum count over 12 months); $\mathrm{N}$ denotes the estimated population globally or on the flyway (WPE5; Wetlands International (2015); http://wpe.wetlands.org/); and $w_{i}$ denotes the weighting of the $i$ th species (IUCN ratings $\mathrm{CR}, \mathrm{EN}, \mathrm{NT}$, and LC, weighted 5, 4, 2, 1, respectively) of the 46 species.

\section{Results}

\section{Potential habitats for shorebirds in the study area}

We obtained the rate each environmental variable contributed to the distribution of each shorebird species from the MaxEnt model. Redundant variables, those that contributed less than 1\%, were excluded ( $\mathrm{Li}$ et al. 2017); remaining variables were used in the following simulation. The AUC value of the average training set of 10 cross-validated runs for each shorebird exceeded 0.7 for all species, implying our model could accurately predict the potential distributions of these species.

For $33(71.7 \%)$ of the 46 shorebird species, 'land use' contributed more than $50 \%$ (Fig. S1) to the distribution of species, indicating this environmental variable was the most important factor determining shorebird habitat selection.

The MaxEnt model also produced a probability distribution map for the 46 shorebird species (Fig. S2). Overlaying both probability distribution and land use maps it was apparent that shorebirds were largely reliant on the coast throughout the study area, especially 
within Liaoning province, Bohai Bay (Hebei province and Tianjin municipality), Laizhou Bay (Shandong province), and Lianyungang and Yancheng cities and the coasts of Rudong and Dongtai counties (Jiangsu province). Based on the response curves for the probability of distribution relative to land-use type, tidal flats also represented the most suitable habitat for these shorebird species throughout this region (Fig. S3).

\section{Identification of priority areas and gap analysis}

Our nested hierarchical landscape sequence (based on the Zonation model) was divided into four protection value categories (Fig. 2a), with protection priority areas identified in Fig. 2b; the total priority area, $4523 \mathrm{~km}^{2}$, and land use composition are detailed in Table 2. Priority areas contained more tidal flats (in particular), and saltpan and aquaculture areas.

The distributions of NNRs and our priority areas were overlain to identify gaps in conservation (Fig. 3). Only $12.05 \%$ of proposed priority areas were included within existing NNRs (Table 3). More than $90 \%$ of tidal flat areas were located in priority areas. The main distributions of the 46 shorebird species we survey were within areas currently afforded no conservation. Although the rate of protection of tidal flats was greater than other land-use types, the distribution of protected areas along the coasts of China was imbalanced, with nearly all tidal flats in Rudong and Dongtai counties occurring outside protected areas.

\section{Changes to habitat status and conservation importance of the Rudong and Dongtai county coasts}

Our case study focuses on tidal flat reclamation along the Rudong and Dongtai county coasts. Here, land-use conversion from 2000 to 2015 has resulted in a rapid and constant decline in the area of tidal flats available to shorebirds. Decline rates were greatest from 2010 to 2015, during which time almost $207 \mathrm{~km}^{2}$ of tidal flats was lost - a rate of loss nine times that during 2000 to 2010 (Fig. 4). Although the irreplaceability index for this site did not obviously change before 2012, it did increase steeply from 2012 to 2015 (Fig. 5).

\section{Discussion}

We propose protection priority areas for 46 important shorebird species using the MaxEnt species distribution model and Zonation protection planning software. Areas potentially suitable for shorebird species mainly comprise tidal flat, saltpan and aquaculture habitats along the coasts of Liaoning province, Bohai and Laizhou bays, Lianyungang and Yancheng cities, and Rudong and Dongtai counties in Jiangsu Province. Some of these priority areas are consistent with those of Xia et al. (2016), such as areas of Xiaoyangkou, Rudong county, Tiaozini, Dongtai county, and the Yancheng national natural reserve. Our protection priority areas include almost all tidal flat environment (more than $90 \%$ of existing tidal flats), indicating the importance of this habitat type to shorebirds.

Of particular concern to us is the decrease in area of tidal flats throughout this region over time, and the concomitant and dramatic decrease in shorebird populations (Studds et al. 2017; Yang et al. 2011, 2017). Additionally, the functionality of some tidal flats has degraded and may no longer meet the foraging requirements of migrating shorebirds (Hou 2011; Lourenço et al. 2018). Long-term field observations carried out by Zhijun Ma's team from Fudan University have reported food resources in Yalu Estuary no longer support 


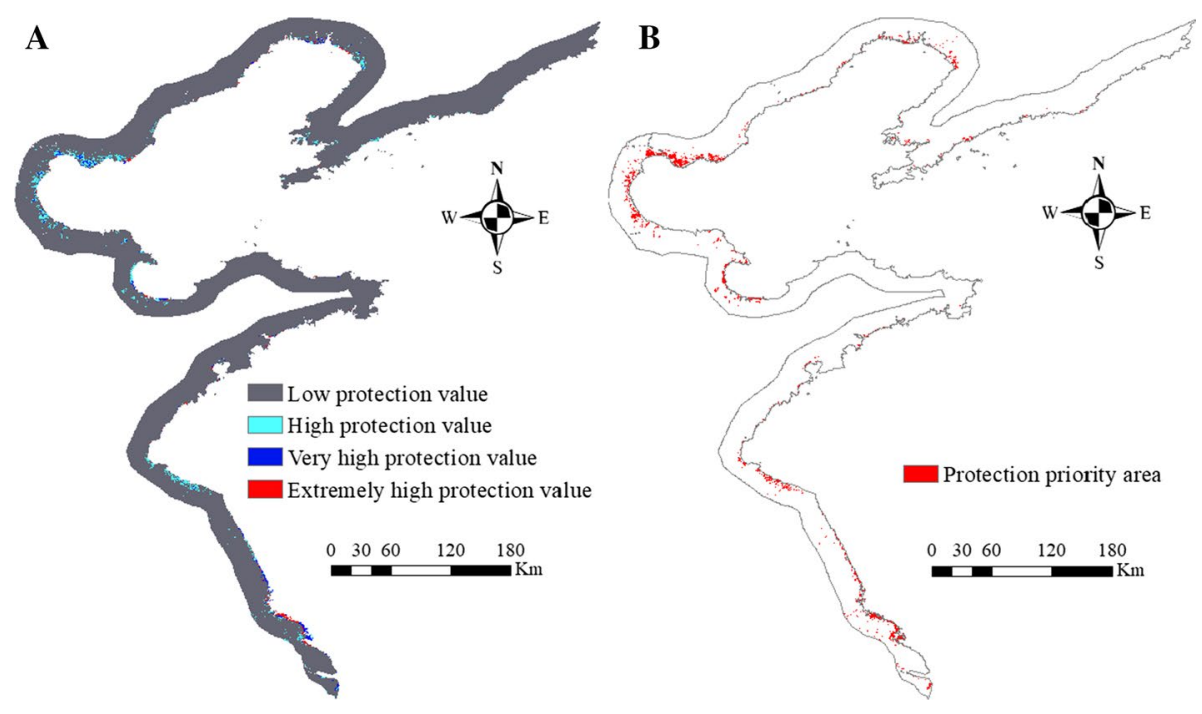

Fig. 2 a The map of conservation value. b Protection priority area

Table 2 Proportional representation of landuse categories within priority areas compared to throughout the study area

\begin{tabular}{lccc}
\hline Land-use type & \begin{tabular}{l} 
Area $\left(\mathrm{km}^{2}\right)$ \\
Protection \\
\cline { 2 - 3 }
\end{tabular} & $\begin{array}{l}\text { All study area } \\
\text { priority area }\end{array}$ & \\
\hline Tidal flat & 1667 & 1814 & 91.90 \\
Saltpan & 1720 & 7683 & 22.39 \\
Aquaculture & 549 & 7477 & 7.34 \\
Reservoir & 309 & 2649 & 11.66 \\
Bottomland & 85 & 1296 & 6.56 \\
Rice field & 76 & 13,451 & 0.57 \\
Canal & 64 & 1503 & 4.26 \\
Swamp & 33 & 1343 & 2.46 \\
Lake & 20 & 195 & 10.26 \\
\hline
\end{tabular}

migratory shorebird populations - a phenomenon apparent elsewhere in the Yellow and Bohai Seas also (Melville et al. 2016).

Of that area we identify as requiring prioritized conservation, $87.95 \%$ of it, mainly tidal flat, saltpan and aquaculture habitats, is not protected within any existing NNR. Despite providing important habitat for shorebirds, tidal flats are also poorly protected in that area in Rudong and Dongtai counties under consideration as a World Heritage area.

We analyzed Changes in habitat status and conservation importance along the coasts of Rudong and Dongtai counties that until 2015 lacked protection. Between 2012 and 2015, concomitant with a decrease in tidal flat area, the importance of this habitat to conservation increased considerably. Although, we could only analyze changes in the conservation importance of tidal flat habitat throughout the Xiaoyangkou area, Rudong county, numbers of spoon-billed sandpipers increased in Tiaozini, Dongtai county, between 2010 and 2015 (Peng et al. 2017a, b). 


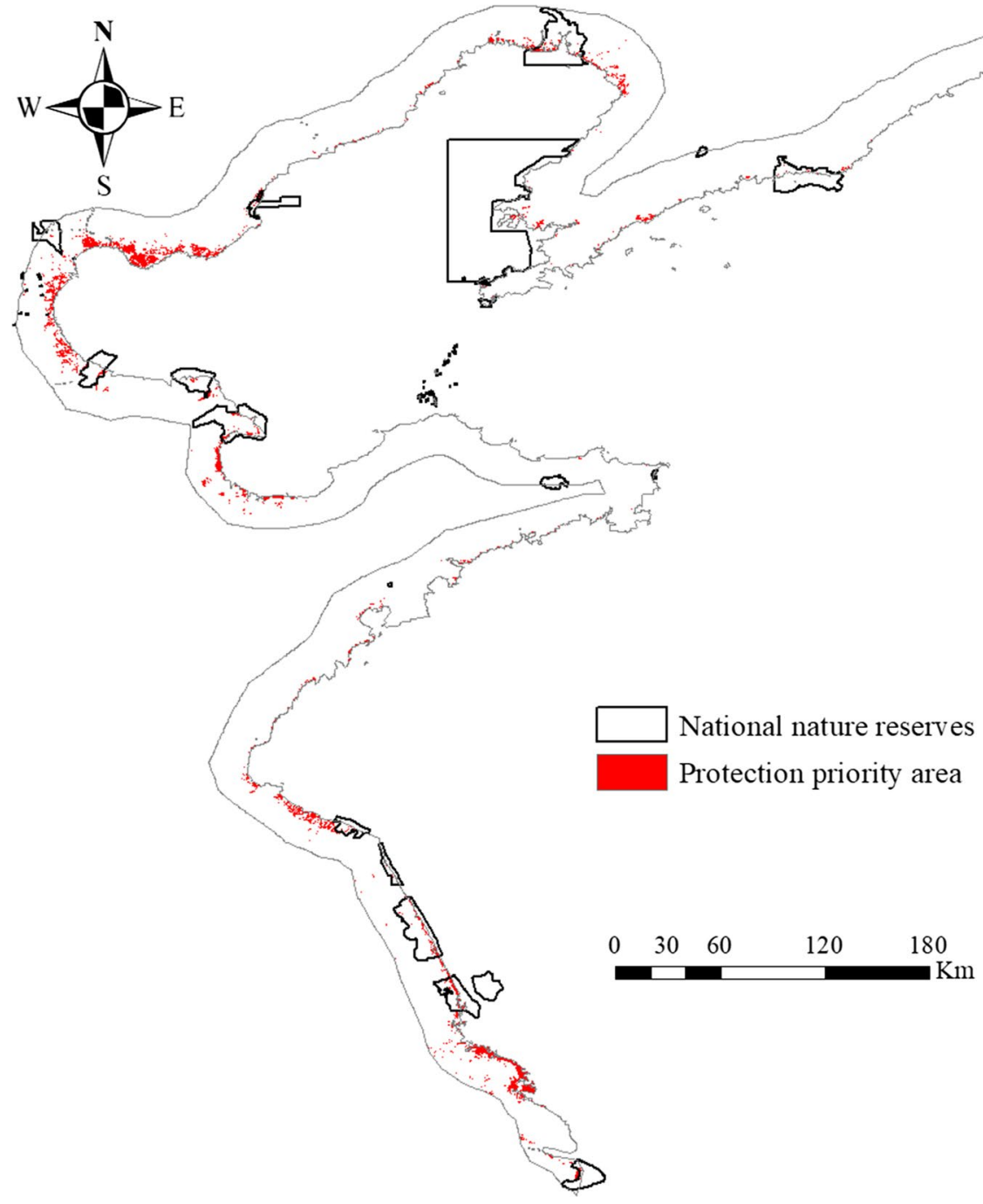

Fig. 3 Distribution of current National Nature Reserves, and areas identified as appropriate for prioritized conservation (emphasizing the gaps in protection of important habitat throughout the study area)

Appropriate and timely action is necessary to preserve remaining tidal flat habitat throughout this region, and to improve its ecological function. Moreover, unprotected wetland, and land already developed for aquaculture and saltpan use (converted from tidal flats) that has conservation value, also requires protection, as it too can provide important habitat for shorebirds. Some of the 46 shorebird species we report are known from aquaculture and saltpan land types, even during the winter southern migration. Drained aquaculture ponds can provide mudflat habitat for shorebirds during winter (Choi et al. 2014; Liao et al. 2013; Rocha et al. 2017). Additionally, saltpan habitat is used not only by shorebirds at high tide (Melville et al. 2016), but some large shorebird species actually prefer feeding in this habitat (Sripanomyom et al. 2011; Yasué and Dearden 2009). Improving 
Table 3 The area and proportion of habitat types in areas we prioritize for conservation currently protected in National Nature Reserves (NNRs) as of 2014

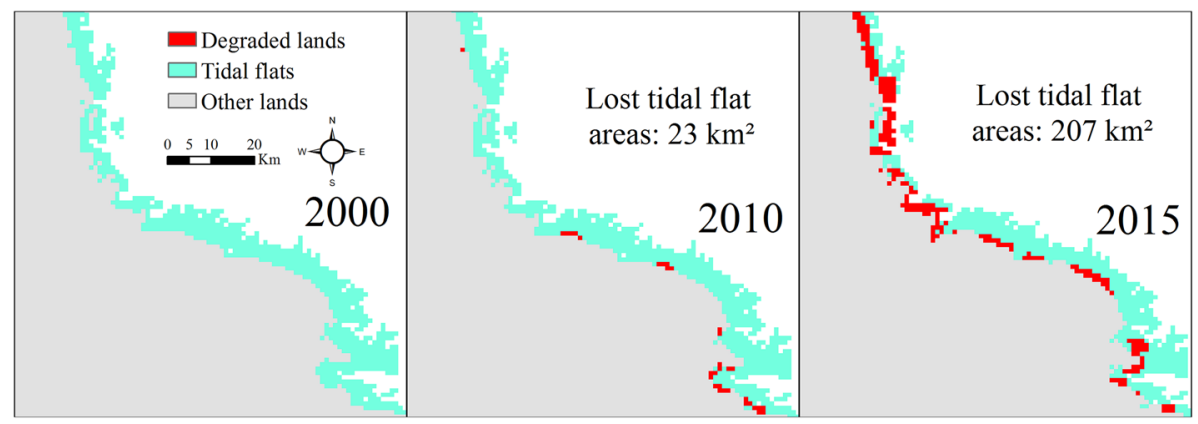

Fig. 4 Tidal flat reclamation 2000-2015 in coastal wetland of Rudong and Dongtai counties

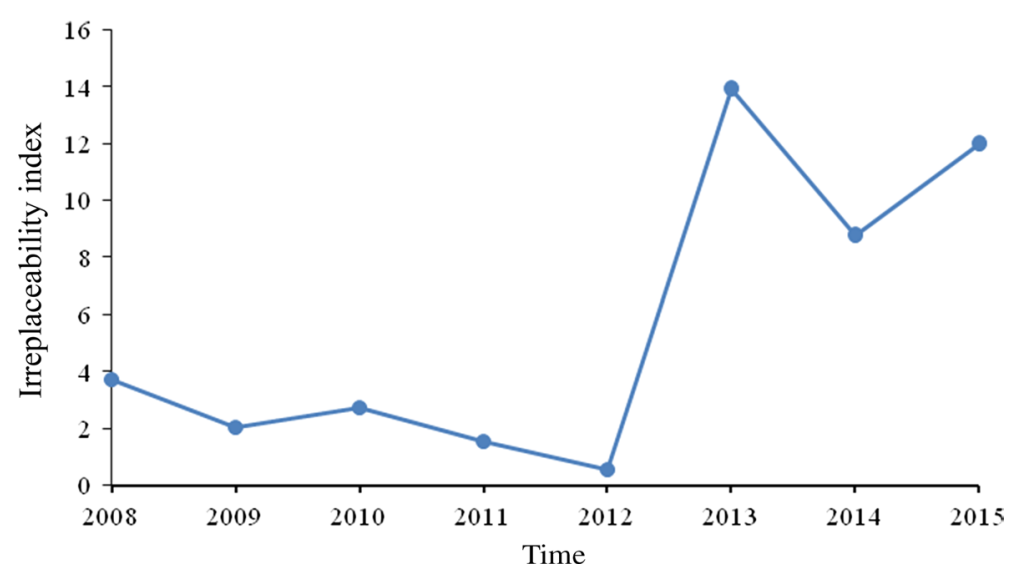

Fig. 5 Change in habitat irreplaceability index over time for the coastal region of Xiaoyangkou, Rudong county

\begin{tabular}{lccc}
\hline Type & Area $\left(\mathrm{km}^{2}\right)$ & \multicolumn{2}{l}{ NNRs } \\
\cline { 3 - 4 } & & Covered $(\%)$ & Uncovered $(\%)$ \\
\hline Tidal flat & 1667 & 25.19 & 74.81 \\
Saltpan & 1720 & 4.24 & 95.76 \\
Aquaculture & 549 & 5.10 & 94.90 \\
Reservoir & 309 & 1.94 & 98.06 \\
Bottomland & 85 & 12.94 & 87.06 \\
Rice field & 76 & 1.32 & 98.68 \\
Canal & 64 & 0.00 & 100.00 \\
Swamp & 33 & 3.03 & 96.97 \\
Tidal flat & 20 & 25.00 & 75.00 \\
Total & 4523 & 12.05 & 87.95 \\
\hline
\end{tabular}


conservation of artificial wetlands might mitigate against the effects of natural wetland loss on shorebirds (Ma et al. 2010; Wang et al. 2018; Lei et al. 2018).

Despite the Chinese government implementing policies and counter-measures to address problems arising from reclamation, including prohibition of further coastal reclamation, the historical high intensity of coastal wetland reclamation still requires shorebird protection be urgently redressed (Hua et al. 2015; Melville et al. 2016). Identification of areas for priority protection is an important first step for biodiversity conservation, but it is critical that action based on these recommendations is taken (Game et al. 2012). First, protected areas should be enlarged, and new nature reserves that include key shorebird habitat (tidal flats) established, especially along the coasts of Rudong and Dongtai counties (Triviño et al. 2018; Tu et al. 2014). Second, artificial wetlands should be better managed (Navedo et al. 2016; Erwin et al. 1986), especially those tidal flats along Bohai and Laizhou bays coasts that have been converted for saltpan or aquaculture usage.

The potential for artificial wetland areas to provide habitat for shorebirds has been often neglected. Most of these areas supply food and products for local communities, leading to conflict between the competing demands of people and the needs of shorebirds (Wang et al. 2018). Therefore, balancing the needs of shorebird conservation and local communities is an issue that must be addressed. As a preliminary measure, we suggest targeting key priority areas, for example, saltpans and aquaculture areas in Bohai and Laizhou bays, in which habitat restoration experiments could be undertaken. In saltpan habitat, experiments might actively manage low water levels, while in aquaculture areas, management might include leaving some product unharvested as food for shorebirds (Dias et al. 2014; Ma et al. 2010). Controlling the intensity of shellfish collection, or compensating locals for losses to feed shorebirds in these areas are other possible approaches to conflict resolution (Navedo and Masero 2010; Amano et al. 2017).

Our data for 46 shorebird species occurring within the intertidal area of the Yellow and Bohai Seas identifies a significant proportion (87.95\%) of important habitat that remains unprotected. Accordingly, a need exists to protect further coastal land from reclamation, in addition to existing modified habitat (such as aquaculture and saltpan lands) within a protected area network. Our methodology could be applied to protect habitat, animals and plants, and functional groups in other areas also (Parsons 2002; Stafford Stafford et al. 2010).

\section{Conclusions}

Our analyses identify priority areas for shorebird conservation to occur mainly along the coasts of Bohai and Laizhou bays, Lianyungang and Yancheng cities, and Rudong and Dongtai counties. Many shorebird habitats remain unprotected, especially tidal flats in Rudong and Dongtai counties, and saltpan and aquaculture habitats in Bohai and Laizhou bays. The tidal flat area in Rudong and Dongtai counties has decreased constantly from 2000, while its conservation importance has increased since 2012. An urgent need to protect this habitat type exists, and we recommend immediate establishment of new natural reserves in remaining coastal tidal flats throughout this region, such as tidal flats in Rudong and Dongtai counties. We also suggest enhancement of management and restoration of artificial wetland areas, such as saltpan and aquaculture habitat in Bohai and Laizhou bays, to more appropriately conserve remaining habitat for migratory shorebirds. 
Acknowledgements This research was jointly supported by Earth big data Scientific Engineering project of Chinese Academy of Sciences (Grant No. XDA19020305), Science and Technology Service Network Initiative (STS) Project of the Chinese Academy of Sciences (Grant No: KFJ-STS-ZDTP-023), the National Natural Science Foundation of China (Grant No. 41701212), and Developing China's Coastal WaterBirds and Habitats Database Project which is funded by The Paulson Institute and The Lao Niu Foundation. We thank the Bird Watching Network website and the China Coastal Waterbird Census Team for providing data collection support.

Author contribution XY planned and designed the research; HD, SX, XH and Y L collected data; HD analyzed data and wrote the manuscript; XY and SX revised the manuscript.

Data availability Data used in this manuscript are shared from "Bird Report (http://birdreport.cn/bird/)." Detail data information should contact to Xiubo Yu (yuxb@igsnrr.ac.cn).

\section{References}

Alagador D, Cerdeira JO, Araújo MB (2016) Climate change, species range shifts and dispersal corridors: an evaluation of spatial conservation models. Methods Ecol Evol 7:853-866

Amano T, Székely T, Sandel B, Nagy S (2017) Successful conservation of global waterbird populations depends on effective governance. Nature 553:199-202

Bai QQ, Chen JZ, Chen ZH, Dong GT, Dong JT, Dong WX, Fu VWK, Han YX, Lu G, Li J, Liu Y, Lin Z, Meng DR, Martinez J, Ni GH, Shan K, Sun RJ, Tian SX, Wang FQ, Xu ZW, Yu YT, Yang J, Yang ZD, Zhang L, Zhang M, Zeng XW (2015) Identification of coastal wetlands of international importance for waterbirds: a review of China Coastal Waterbird Surveys 2005-2013. Avian Res 6:1-16

Battley P (2004) Shorebirds of the Yellow Sea: importance, threats and conservation status by M. Barter. Emu 104(3):299

Bastos AM (2013) Conservation planning with uncertain climate change projections. PLoS ONE 8:e53315

BirdLife International (2019) Country profile: China (mainland). Available from http://www.birdlife.org/ datazone/country/china. Accessed 29 June 2019

Chen KL, Yang XZ, Lv Y (2015) Vital stopover of shorebirds migration on the East Asian-Australasian flyway: wetlands of Yellow and Bohai Sea. Wetl Sci 13:1-6

Choi C, Gan X, Hua N, Wang Y, Ma ZJ (2014) The habitat use and home range analysis of Dunlin (Calidris alpina) in Chongming Dongtan, China and their conservation implications. Wetlands 34:255-266

Dias MP, Lecoq M, Moniz F (2014) Can human-made saltpans represent an alternative habitat for shorebirds? Implications for a predictable loss of estuarine sediment flats. Environ Manag 53:163-171

Erwin RM, Coulter M, Cogswell H (1986) The use of natural vs. man-modified wetlands by shorebirds and waterbirds. Colon Waterbird 9:137-138

Game ET, Kareiva P, Possingham HP (2012) Six common mistakes in conservation priority setting. Conserv Biol 27:480-485

Harte J, Newman EA (2014) Maximum information entropy: a foundation for ecological theory. Trends Ecol Evol 29:384-389

Hou SL (2011) Community of macrobenthic and shorebirds in YanCheng Nature Reserve. Nanjing Forestry University, Nanjing, pp 1-79

Hu R, Wen C, Gu Y, Wang H, Gu L, Shi XY, Zhong J, Wei M, He FQ, Lu Z (2017) A bird's view of new conservation hotspots in China. Biol Conserv 211:47-55

Hua N, Tan K, Chen Y, Ma ZJ (2015) Key research issues concerning the conservation of migratory shorebirds in the Yellow Sea region. Bird Conserv Int 25:38-52

Institute Paulson (2016) Blueprint of coastal wetland conservation and management in China. Institute of Geographic Sciences and Natural Resources Research, CAS, Beijing, pp 45-50

IUCN (2019) The IUCN Red List of Threatened Species. Version 2019-1. https:/www.iucnredlist.org. Accessed 16 Oct 2018

IUCN World Heritage Evaluations (2019) https://www.iucn.org/. Accessed 8 July 2019

Lei WP, Masero JA, Piersma T, Zhu BR, Yang HY, Zhang ZW (2018) Alternative habitat: the importance of the Nanpu Saltpans for migratory waterbirds in the Chinese Yellow Sea. Bird Conserv Int 28:549-566

Li LH, Liu HY, Lin ZS, Jia JH, Liu X (2017) Identifying priority areas for monitoring the invasion of Solidago canadensis based on MAXENT and ZONATION. Acta Ecol Sin 37:3124-3132

Liao XW, Zhou LU, Shu XL, Li YL, Yang G, Zhou F (2013) Habitat selection analysis of wintering shorebirds at Qinzhou Bay, Guangxi. Chin J Zool 48:693-700 
Lourenço PM, Granadeiro JP, Catry T (2018) Low macroinvertebrate biomass suggests limited food availability for shorebird communities in intertidal areas of the Bijagós archipelago (Guinea-Bissau). Hydrobiologia 816:197-212

Ma ZJ, Cai Y, Li B, Chen JK (2010) Managing wetland habitats for waterbirds: an international perspective. Wetlands 30:15-27

Ma TT, Chen L, Li XW, Tian X, Cui BS (2015) Quantitative assessment of impacts of reclamation activities on coastal wetlands in China. Wetl Sci 13:654-659

Ma ZJ, Chen Y, Melville DS, Fan J, Liu JG, Dong JW,Tan K, Cheng XF, Fuller RA, Xiao XM, Li B (2019) Changes in area and number of nature reservesin China. Conserv Biol (Accepted)

Melville DS, Chen Y, Ma ZJ (2016) Shorebirds along the Yellow Sea coast of China face an uncertain future-a review of threats. Emu 116:100-110

Moilane A, Pouzols FM, Meller L (2014) Zonation: spatial conservation planning and methods software \pm User Manual, Version 4. University of Helsinki, C-BIG Conservation Biology Informatics Group, Department of Bioscience, Helsinki

Murray NJ, Fuller RA (2015) Protecting stopover habitat for migratory shorebirds in East Asia. J Ornithol $156: 217-225$

Murray NJ, Clemens RS, Phinn SR, Possingham HP, Fuller RA (2014) Tracking the rapid loss of tidal wetlands in the Yellow Sea. Front Ecol Environ 12:267-272

Murray NJ, Ma ZJ, Fuller RA (2015) Tidal flats of the Yellow Sea: a review of ecosystem status and anthropogenic threats. Aust Ecol 40:472-481

Navedo JG, Masero JA (2010) Measuring potential negative effects of traditional harvesting practices on waterbirds: a case study with migrating curlews. Anim Conserv 10:88-94

Navedo JG, Fernánde Z, Guillermo VN, Drever MC (2016) Data from: identifying management actions to increase foraging opportunities for shorebirds at semi-intensive shrimp farms. J Appl Ecol 54:567-576

Niu JY (2013) Habitat selection and diversity change of waterbirds community in reclaimed coastal wetlands in Nanhui Dongtan, Shanghai, China. East China Normal University, Shanghai, pp 55-66

Nori J, Lescano JN, Illoldi-Rangel P, Frutosd N, Cabrerabe MR, Leynauda GC (2013) The conflict between agricultural expansion and priority conservation areas: making the right decisions before it is too late. Biol Conserv 159:507-513

Parsons KC (2002) Integrated management of waterbird habitats at impounded wetlands in Delaware Bay, U.S.A. Waterbirds 25:25-41

Peng HB, Anderson GQA, Chang Q, Choi CY, Chowdhury SU, Clark NA, Gan XJ, Hearn RD, Li J, Lappo EG, Liu WL, Ma ZJ, Melville DS, Phillips JF, Syroechkovskiy EE, Tong M, Wang SL, Zhang L, Zöckler C (2017a) The intertidal wetlands of southern Jiangsu Province, China-globally important for spoon-billed sandpipers and other threatened waterbirds, but facing multiple serious threats. Bird Conserv Int 27:1-18

Peng HB, Choi ZY, Zhang L, Gan XJ, Liu WL, Li J, Chiang CY, Wang SL, Ma ZJ (2017b) Distribution and conservation status of the spoon-billed sandpiper in China. Chin J Zool 52:158-166

Piersma T, Chan YC, Mu T, Hassell CJ, Melville DS, Peng HB, Ma ZJ, Zhang ZW, Wilcove DS (2017) Loss of habitat leads to loss of birds:reflections on the Jiangsu, China, coastal development plans. Wader Study 124:1-12

Ramsar Convention Secretariat (2010) Designating Ramsar sites: strategic framework and guidelines for the future development of the List of Wetlands of International Importance. fourth ed. Ramsar Handbooks for the Wise Use of Wetlands vol. 17. Ramsar Convention Secretariat, Gland, Switzerland https ://www.ramsar.org/pdf/lib/hbk4-17.pdf.

Rocha AR, Ramos JA, Paredes T, Masero JA (2017) Coastal saltpans as foraging grounds for migrating shorebirds: an experimentally drained fish pond in Portugal. Hydrobiologia 790:141-155

Sánchez MI, Green AJ, Castellanos EM (2006) Spatial and temporal fluctuations in presence and use of chironomid prey by shorebirds in the Odiel saltpans, south-west Spain. Hydrobiologia 567:329-340

Spiers JA, Oatham MP, Rostant LV, Farrell AD (2018) Applying species distribution modelling to improving conservation based decisions: a gap analysis of Trinidad and Tobago's endemic vascular plants. Biodivers Conserv 27:1-19

Sripanomyom S, Round PD, Savini T, Trisurat Y, Gale GA (2011) Traditional salt-pans hold major concentrations of overwintering shorebirds in Southeast Asia. Biol Conserv 144:526-537

Stafford JD, Kaminski RM, Reinecke KJ (2010) Avian foods, foraging and habitat conservation in world rice fields. Waterbirds 33:133-150

Studds CE, Kendall BE, Murray NJ, Wilson HB, Rogers DI, Clemens RS, Gosbell K, Hassell CJ, Melville DS, Milton DA, Minton CDT, Possingham HP, Riegen AC, Straw P, Woehler EJ, Fuller RA (2017) Rapid population decline in migratory shorebirds relying on Yellow Sea tidal mudflats as stopover sites. Nat Commun 8:14895 
Tong XM, Zhang L, Li J, Zöckler C, Clark NA (2014) The critical importance of the Rudong mudflats, Jiangsu Province, China in the annual cycle of the Spoon-billed Sandpiper Calidris pygmeus. Spoonbilled Sandpiper Task Force News Bull 9:3-5

Triviño M, Kujala H, Araújo MB, Cabeza M (2018) Planning for the future: identifying conservation priority areas for Iberian birds under climate change. Landsc Ecol 33:659-673

Tu Q, Yu H, He Z (2014) Planning the priority protected areas of endangered orchid species in northeastern China. Biodivers Conserv 23:1395-1409

Wang X, Kuang F, Tan K, Ma ZJ (2018) Population trends, threats, and conservation recommendations for waterbirds in China. Avian Res 9:1-13

Watson JEM, Dudley N, Segan DB, Hockings M (2014) The performance and potential of protectedareas. Nature 515:19-25

Wetlands International (2015) Waterbird population estimates, 5th edn. WPE5 http://wpe.wetlands.org/. Accessed 8 Nov 2018

Wu XY, Dong SK, Liu SL, Liu QR, Han YF, Zhang XL, Su XK, Zhao HD, Feng J (2018) Identifying priority areas for grassland endangered plant species in the Sanjiangyuan Nature Reserve based on the MaxEnt model. Biodivers Sci 26:138-148

Xia SX, Yu XB, Millington S, Liu Y, Jia YF, Wang LZ, Hou XY, Jiang LG (2016) Identifying priority sites and gaps for the conservation of migratory waterbirds in China's coastal wetlands. Biol Conserv 210:72-82

Yang HY, Bing C, Mark B, Theunis P, Zhou CF, Li FS, Zheng WZ (2011) Impacts of tidal land reclamation in Bohai Bay, China: ongoing losses of critical Yellow Sea waterbird staging and wintering sites. Bird Conserv Int 2:241-259

Yang H, Ma MG, Thompson JR, Flower RJ (2017) Protect coastal wetlands in China to save endangered migratory birds. PNAS 114:E5491-E5492

Yasué M, Dearden D (1992) Managing artificial saltpans as a waterbird habitat: species' responses to water level manipulation. Colon Waterbird 15:43-55

Yasué M, Dearden P (2009) The importance of supratidal habitats for wintering shorebirds and the potential impacts of shrimp aquaculture. Environ Manag 43:1108-1121

Zwiener VP, Padial AA, Marques MCM, Faleiro FV, Loyola R, Peterson AT (2017) Planning for conservation and restoration under climate and land use change in the Brazilian Atlantic Forest. Divers Distrib 23:955-966

Publisher's Note Springer Nature remains neutral with regard to jurisdictional claims in published maps and institutional affiliations. 